\title{
International Production Sharing and Export Development: An Examination for China and Vietnam
}

\author{
Klimis Vogiatzoglou \\ Hoa Sen University \\ Faculty of Economics and Business \\ Ho Chi Minh City, Vietnam
}

Tel: 84-(08)-3830-1877Ｅ-mail: klimis.vogiatzoglou@hoasen.edu.vn

Received: July 14, 2017 Accepted: August 5, 2017 Published: August 14, 2017

doi:10.5296/jad.v3i2.11561 URL: https://doi.org/10.5296/jad.v3i2.11561

\begin{abstract}
The phenomenon of international production sharing networks (also known as production fragmentation, global value chains, or vertical production networks), which is associated with offshoring/outsourcing, has gained increasingly importance in the contemporary globalization process. This paper analyzes the patterns and trends in international production sharing and export growth in China and Vietnam over the last twenty years. More specifically, in addition to overall trends, our study examines the developments across four broad economic sectors and fifteen manufacturing industries. Furthermore, for both countries the relationship between a country's participation in international production sharing networks and a country's export development (in terms of the domestic value-added content of exports) is investigated through a statistical analysis. The empirical results indicate that China and Vietnam have increased substantially their participation in production networks. Moreover, we find that the extent of a country's involvement in international production sharing highly correlates with improved export performance. This suggests that China's and Vietnam's impressive export expansion over the last twenty years can be attributed, in part, to increasing integration into global value chains.
\end{abstract}

Keywords: Global production networks, Offshoring, Export performance, Domestic value-added exports, Emerging Asian economies 


\section{Introduction}

During the last twenty years global economic integration has proceeded with accelerating steps and moved beyond simple trade relations among countries. This deeper form of globalization has, with increasing intensity, interconnected national economies and transformed the planet into a global market place and production system. There is a considerable amount of accumulated evidence showing that international trade associated with global production sharing has risen much faster than conventional trade (Hanson, 2017; Gupta, 2017; Athukorala, 2014; Bridgman, 2012; Amador and Cabral, 2009; Miroudot and Ragoussis, 2009; Hummels et al., 2001).

The phenomenon of fragmentation is most importantly found in the clothing, automobile, and electronics sectors (Hanson, 2017; Amighini, 2005; Lall et al., 2004). However, global production sharing activities have in recent years grown substantially in other sectors as well.

Particularly for the case of the East Asian region, it is argued that international trade and specialization patterns must be understood in the context of production fragmentation (e.g. Athukorala, 2014; Ando and Kimura, 2009; Haddad, 2007). In fact, large intra- and extra-regional production sharing networks in East Asia have been formed and expanded (Athukorala, 2017; Ing and Kimura, 2017; Li, 2009; Hiratsuka, 2008; Bonham et al., 2007). Nowadays, there exist extensive production sharing links between the economies of Asia-Pacific region, the US, and the European Union. China and, more recently, Vietnam have both witnessed an increasing integration into the global economy. Furthermore, they have attracted large amounts of foreign direct investment (FDI) and increasingly become the target of multinational enterprises which have relocated part of the production process through offshoring to those emerging economies.

As vertical production networks have become a prominent feature of globalization, there is a large and expanding literature on several aspects of production sharing for emerging Asian economies and other countries. However, relatively less attention has been given specifically to the role of international production networks in improving export performance. In fact, there is only a small number of empirical studies that explicitly address the question of how participation in production sharing affects a country's export development (e.g. Chiappini, 2012; Cieslik, 2009; Kimura and Obashi, 2008; Bonham et al., 2007). Interestingly, from a theoretical perspective, exports are likely to be affected positively by global production sharing, as discussed in detail in the next section. In addition, it has also to be pointed out that the phenomenon of production sharing networks is gaining increasingly importance in the contemporary globalization process. Due to the significance of the subject matter coupled with the fact of limited evidence, there is, accordingly, a need for the literature to expand into this direction and provide more information.

Given the above relevant points and the fact that China and Vietnam are increasingly integrating into the global economy, the aim of this paper is to examine for these two emerging economies (i) the trends in the extent of international production sharing, and (ii) the relationship between a country's involvement in production sharing and a country's export development. Our empirical analysis is conducted for the overall economy, for four 


\section{Macrothink}

broad sectors of the economy, and for fifteen manufacturing industries during the period 1995-2014. The rest of the paper continues as follows. Section 2 briefly reviews the relevant theoretical and empirical literature. Section 3 examines the trends and patterns in production sharing. Section 4 analyzes the developments with respect to export expansion. It also investigates the relationship between international production sharing and export development. Finally, Section 5 presents the conclusions.

\section{Conceptual, Theoretical, and Empirical Literature}

International production fragmentation can be described as the phenomenon in which the production of a final good is fragmented or sliced into several production stages which take place in different countries. The various intermediate goods, resulting from each production stage at a different location, are combined in the last stage to produce the final good. International trade in intermediate inputs plays a crucial role here, as it is an integral part of the overall production process. Trade constitutes the necessary link that connects all production blocks.

Figure 1 illustrates graphically the concept of international production fragmentation in the case of a sequential production process of a manufacturing good. Panel (a) of the figure shows the case of a sequential production process that takes place within a vertically integrated firm (where all stages are carried out) or within a country (the firm acquires some of the intermediate production stages only from local suppliers). In this production process some initial raw materials (block A) are being transformed progressively through various stages into processed intermediate goods (blocks B, C, and D) and finally into the final good (final production stage E).

As shown in panel (b), with international production fragmentation only a subset of the sequential production stages are being carried out in the home country (A), while the remaining blocks are produced in another country (B). In particular, in our simplified example with two countries, "country A" produces the production stage (intermediate good) $\mathrm{B}$, which is exported to "country B" (grey dotted arrow). By using this imported intermediate good, "country B" produces the intermediate sequential production stages $\mathrm{C}$ and $\mathrm{D}$. The production block D is then exported to "country A", where the final transformation occurs, resulting in the final consumer good (stage E).

There is a growing theoretical literature on trade in intermediate goods and production fragmentation (e.g. Sanyal and Jones, 1982; Jones and Kierzkowski, 1990; Kimura and Ando, 2005; Grossman and Helpman, 2002; Arndt and Kierzkowski, 2001; Deardorff, 2001). Notably, production sharing has a number of important implications with regard to the traditional concept of comparative advantage, trade patterns, wages, and employment (Baldone et al., 2007). Countries can no longer be thought of as producers of a particular final product. On the contrary, countries produce one or more segments of the overall production process (as illustrated in Figure 1). 


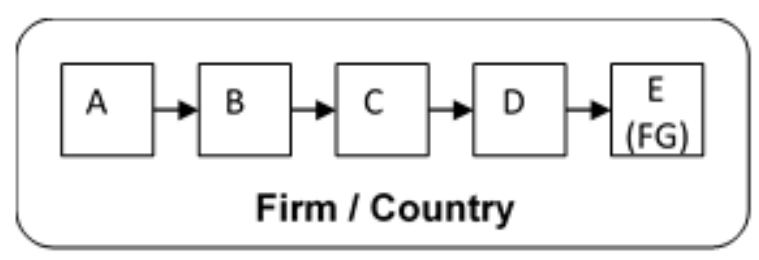

(a) The production process within a vertically integrated firm or within a country

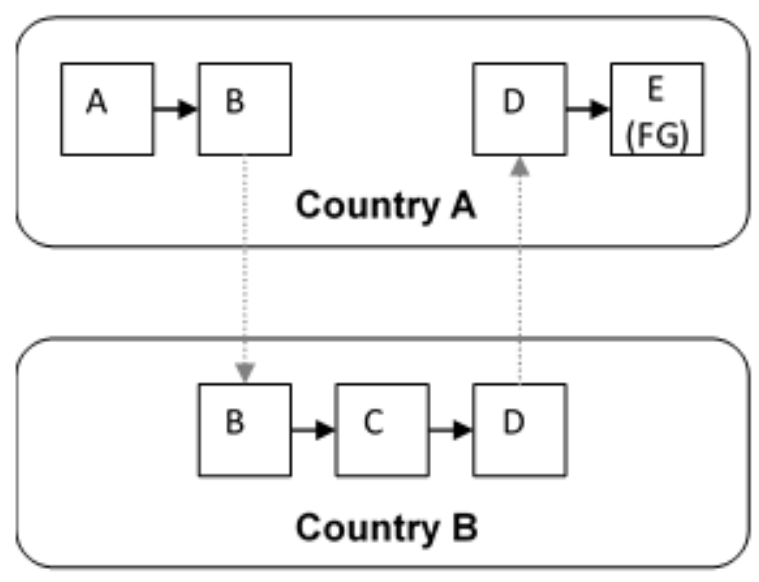

(b) The production process with international production sharing

Source: Own compilation.

Figure 1. An Illustration of Regular Production vs. International Production Sharing

In the case of production sharing, the comparative advantage concept (Ricardian and Heckscher-Ohlin (H-O) trade theory) loses its traditional meaning with respect to production and international specialization. Here, comparative advantage (due to cross-country differences in labor productivities and relative factor endowments) relates to the individual production segments or blocks.

For instance, if the various segments (blocks) of the production process require different labor skills, a Ricardian specialization pattern can be generated, by allocating appropriately the segments across countries. Countries that exhibit a comparative advantage (labor productivity) in a particular production segment, will specialize in this segment. Similarly, if the production segments require factors (production inputs) in different proportions, countries will specialize in segments, in which their relative factor endowments match the relative input requirements ( $\mathrm{H}-\mathrm{O}$ specialization). The above discussion suggests that international production sharing can be beneficial and promote economic efficiency.

It has to be noted that there is no complete analytical international trade theory with production sharing that predicts the effects on export performance. However, various models 
imply that there is a positive impact of production sharing networks on the exports of the participating countries. For instance, taking an $\mathrm{H}-\mathrm{O}$ view with 2 countries and 2 goods (where one good is fragmented), Arndt's (2001) examination reveals that with fragmentation within a free trade area leads both countries to produce and export different intermediates (production stages) of the fragmented good. Both countries continue to produce the final good with the fragmented technology (imported intermediate goods), and the bilateral trade occurs in the components of the fragmented good. The output of this final good in both countries increases due to lower overall production costs and increased productivity, as does the export volume. An implication is that their exports of the fragmented good could also rise towards third countries, as they produce with lower costs compared to countries that do not use the fragmented production process.

In a similar theoretical exercise, Deardorff (2001) examines the issue with both a graphical and a formal mathematical analysis within a Ricardian as well as H-O setting. Several outcomes are possible. Depending on how and whether fragmentation changes the prices, a country could specialize completely in the intermediate good and export it. In this case, the partner country would import the intermediate good and specialize in the production of the final good. Also, both countries would experience an increase in their output and export level. In more formal and general equilibrium analyses, where fragmentation is allowed to occur in any sector and direction, typically a large number of results can be generated and the outcomes are rather ambiguous (depending on certain conditions) than straightforward predictions. Although the results are not clear-cut, a typical scenario is that the countries engaging in international production sharing, experience an expansion in output and exports (e.g. Baldwin and Robert-Nicoud, 2014; Markusen and Venables, 2007).

The results of the rather small empirical literature with regard to the impact of production sharing on exports suggest that there is such a positive effect. More specifically, Cieslik's (2009) findings indicate that together with other country-level determinants vertical production networks explain Poland's trade with its trading partners. For seven East Asian economies, Bonham et al. (2007) find that fragmentation has a particularly strong and statistically significant effect on a country's ICT exports. Srholec's (2007) study, which includes several East Asian, developing, and developed countries, also finds strong econometric evidence of a significant impact of production sharing on electronics exports. Finally, Kimura and Obashi (2008) examine this issue for China using regional data. It is found that the observed differences in export performance in electronics and machinery products across Chinese regions is partly explained by the cross-regional differences in the extent of participation in the East Asian production sharing networks.

\section{International Production Sharing Developments in China and in Vietnam}

There are various indicators in the literature that could be used as a measure of the extent of a country's international production sharing (e.g. Hummels et al., 2001 index, inward/outward FDI). These indicators do not reflect adequately the phenomenon of production sharing and do not provide sector-specific information. For instance, FDI flowing into a country may not be related to production fragmentation at all, as it might be of the horizontal type. Therefore, 


\section{Al Macrothink}

overall FDI flows do not indicate a country's extent of international production fragmentation. Only vertical FDI is associated with production sharing. Besides data availability issues, one major disadvantage of vertical FDI is that it reveals only production sharing among countries undertaken by multinational enterprises. However, fragmentation occurs also to a large extent between independent firms (at arm's length transactions).

Therefore, our analysis on the developments of international production sharing is based on an appropriate measure of the extent and value of cross-border production fragmentation. This indicator, which provides information for the aggregate economy as well as for individual sectors, is the foreign value-added (imported intermediate inputs) in domestic production, which is based on international input-output data and compiled by the OECD Trade in Value-added (TiVA) database. Using this measure, we examine the overall extent of China's and Vietnam's involvement in international production networks. Additionally, we conduct a disaggregated analysis: (i) for four broad economic sectors, and (ii) for 15 manufacturing industries. From the TiVA database we also obtain data on exports that include only domestic value-added. The analysis on export development is presented in the next section, in which the connection between production sharing and exports is also explored.

First, we trace the patterns and trends in the foreign value-added in domestic production (FVP) between 1995 and 2014 (which is the latest available year) for China and Vietnam. Figure 2 shows international production sharing developments at the aggregate level in China and Vietnam, as indicated by the aggregate FVP measure. It is evident that there is an increasing trend in both countries. However, China's FVP value is much larger. This difference in the absolute value can mainly be explained by the huge size differences between those countries.

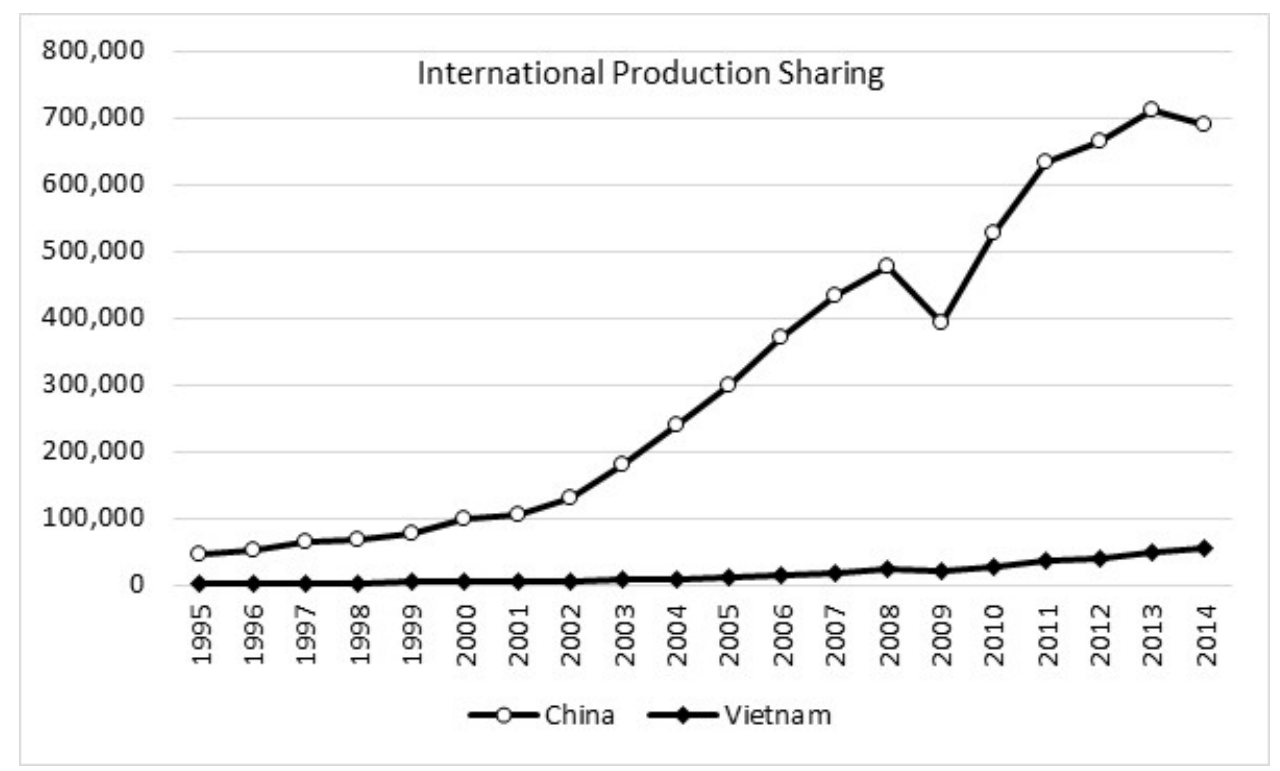

Source: For all Figures: Own compilation based on data from OECD TiVA database

Figure 2. International production sharing (FVP): China vs. Vietnam (mill. US dollars) 


\section{Macrothink}

Journal of Asian Development

ISSN 2377-9594

2017, Vol. 3, No. 2

Figure 3 depicts the aggregate FVP trends only in Vietnam in order to provide a clearer picture of the long-run developments in that country. It becomes clear that Vietnam's participation in international production sharing networks increased substantially during the 1995-2014 period. Although we see overall an increase, the above analysis does not reveal in which economic sectors production sharing is more prevalent. This is shown for four broad economic sectors in China and Vietnam in Figures 4 and 5, respectively.

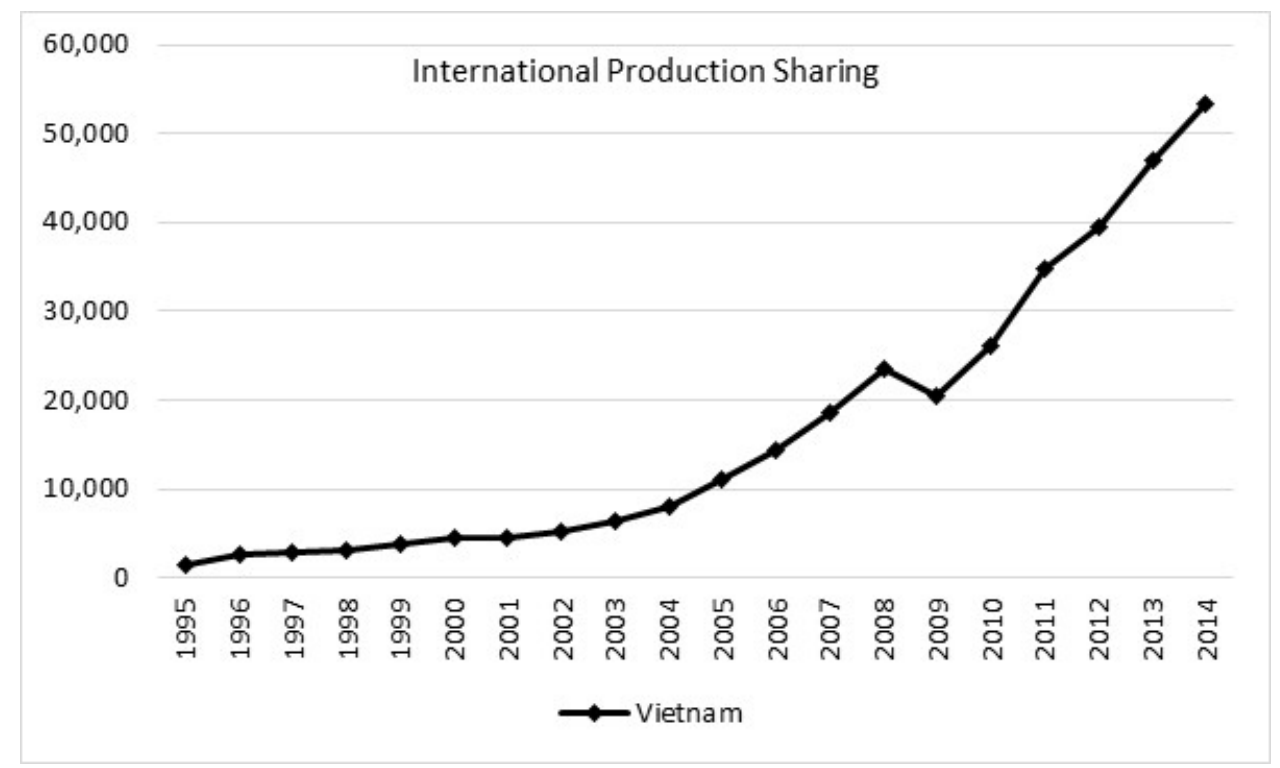

Figure 3. International production sharing (FVP) in Vietnam (mill. US dollars)

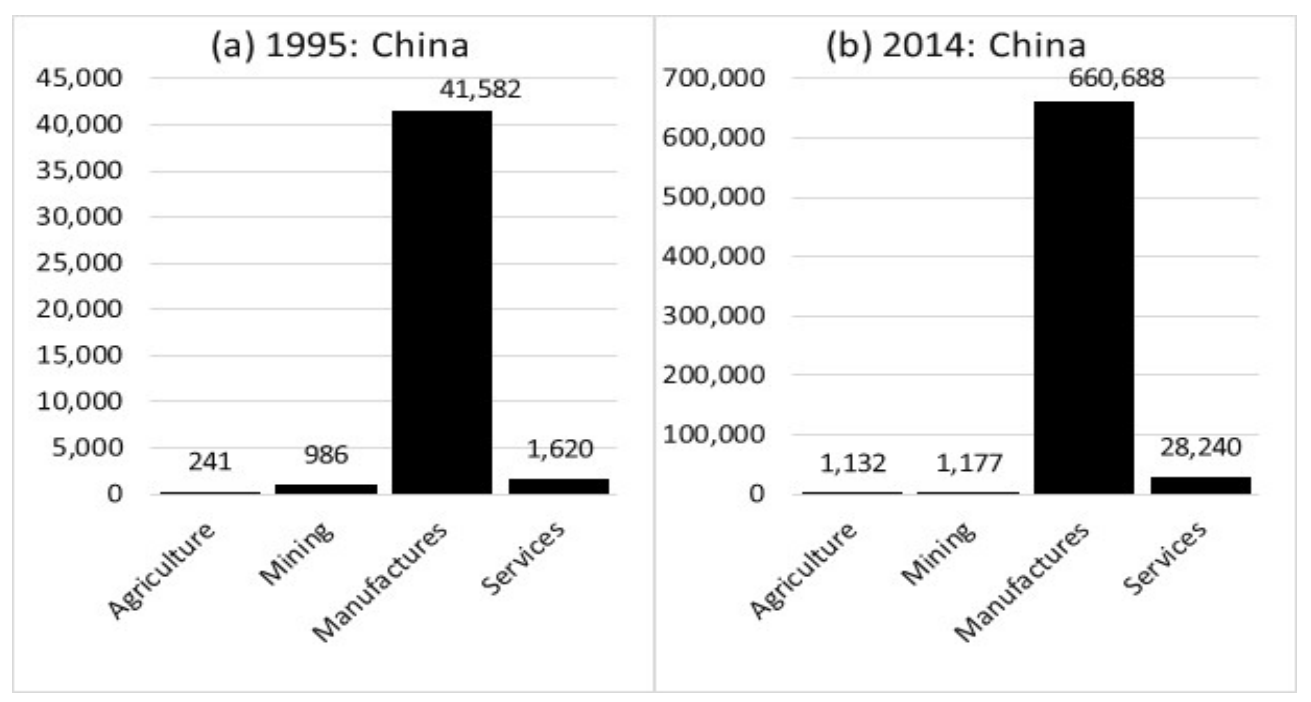

Figure 4. International production sharing across broad economic sectors in China 


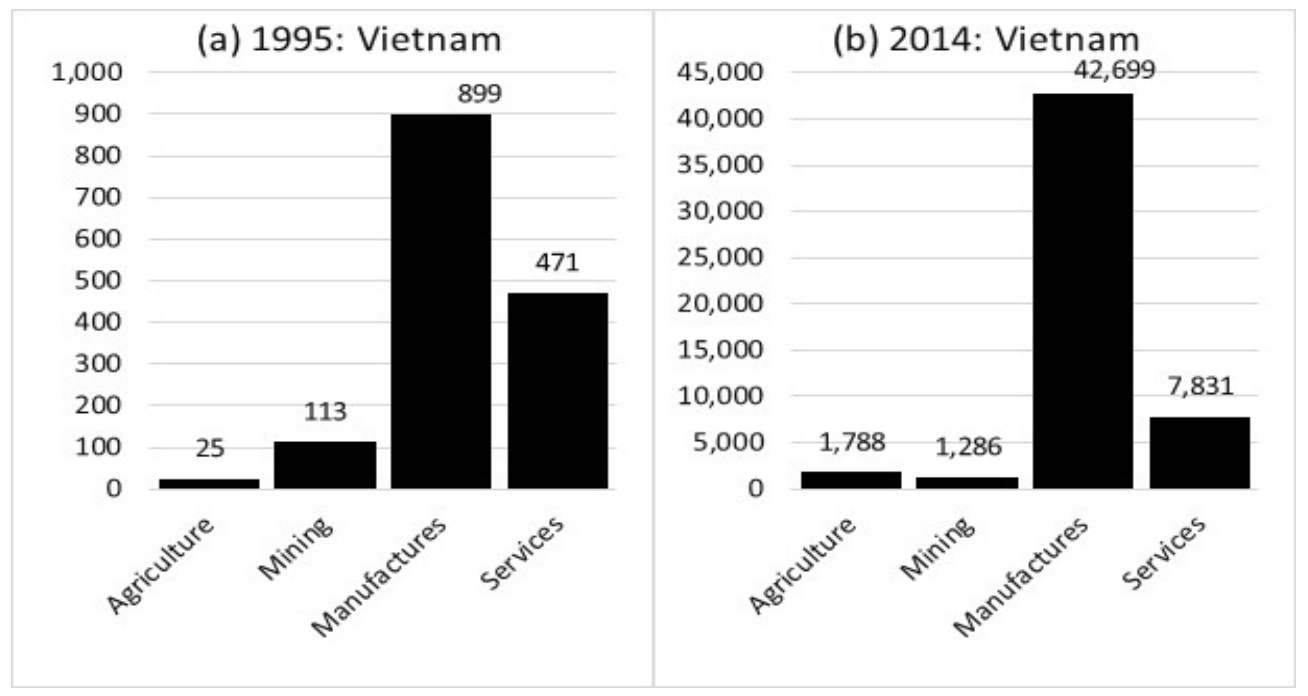

Figure 5. International production sharing across broad economic sectors in Vietnam

Table 1. Classification and Definition of Manufacturing Industries

\begin{tabular}{lll}
\hline Sector No. & ISIC Code* & Description of Manufacturing Sector \\
\hline 1 & C15T16 & Food products, beverages and tobacco \\
2 & C17T19 & Textiles, textile products, leather and footwear \\
3 & C20 & Wood and products of wood and cork \\
4 & C23 & Pulp, paper, paper products, printing and publishing \\
5 & C21T22 & Coke, refined petroleum products and nuclear fuel \\
6 & C24 & Chemicals and chemical products \\
7 & C25 & Rubber and plastics products \\
8 & C26 & Other non-metallic mineral products \\
9 & C27 & Basic metals \\
10 & C28 & Fabricated metal products \\
11 & C29 & Machinery and equipment, nec \\
12 & C30T33X & Computer, Electronic and optical equipment \\
13 & C34 & Motor vehicles, trailers and semi-trailers \\
14 & C35 & Other transport equipment \\
15 & C36T37 & Manufacturing nec, recycling
\end{tabular}

*ISIC stands for International Standard Industrial Classification.

It is apparent that the manufacturing sector is by far the most important sector with respect to international production sharing in both countries. This is especially true in China. In 


\section{Macrothink}

Vietnam, other sectors (most importantly the service sector) also exhibit a high degree of participation in production networks. Between 1995 and 2014 the value of FVP in the manufacturing sector increased substantially. This suggests that international production sharing is mostly a phenomenon associated with manufacturing activities. This is in complete accordance with the conceptual and theoretical framework of international production fragmentation. As discussed in section 2, the production process of many manufacturing activities can be internationally fragmented. This results in the creation of production blocks and components, which are shipped to other countries for further processing. Finally, it is informative to have a closer look at manufacturing and examine the production sharing developments across manufacturing industries. The OECD's TiVA database provides also disaggregated information on 15 manufacturing industries. The definitions and descriptions of those industries are reported in Table 1. Figures 6 and 7 show the extent of production sharing across 15 manufacturing industries between 1995 and 2014 in China and Vietnam, respectively.

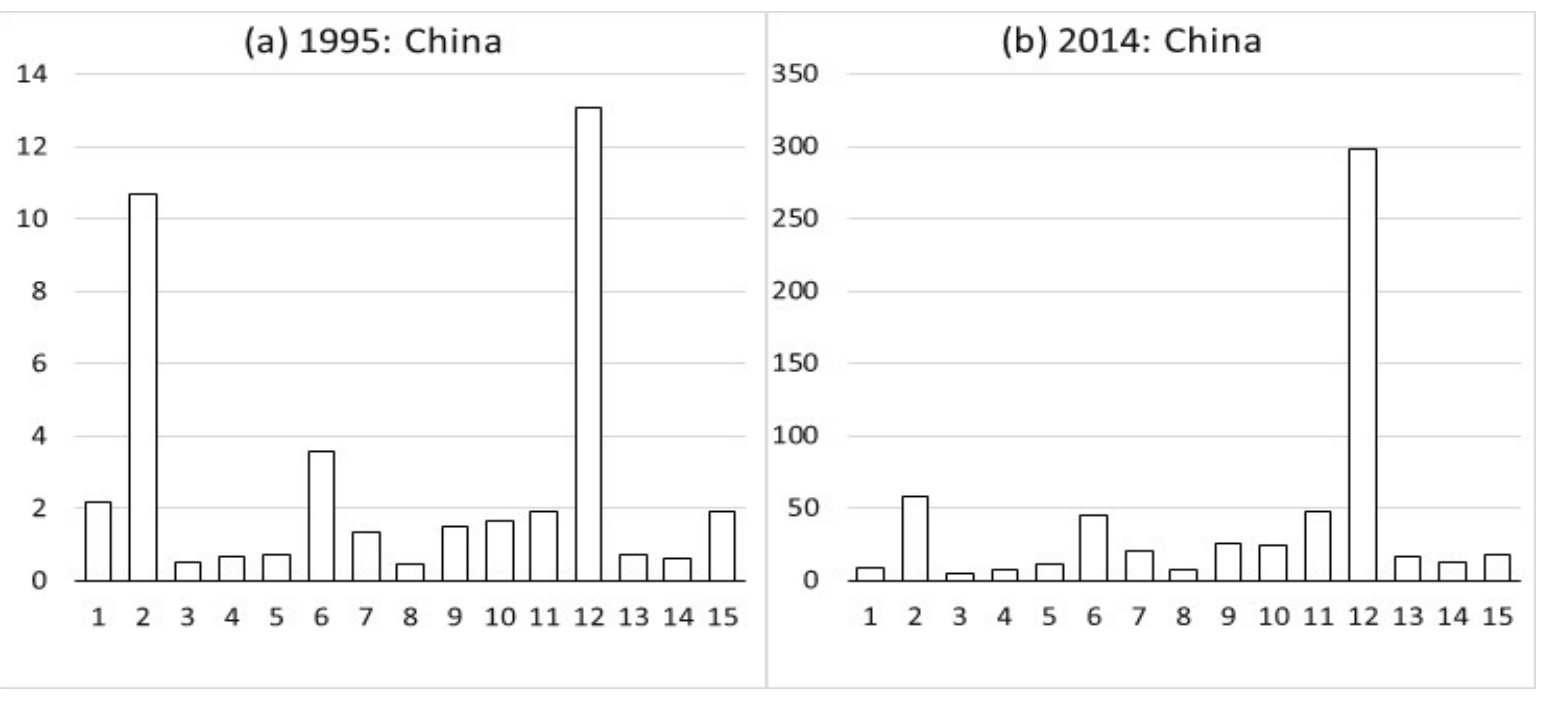

Figure 6. International production sharing across 15 manufacturing industries in China 


\section{Mll Macrothink}

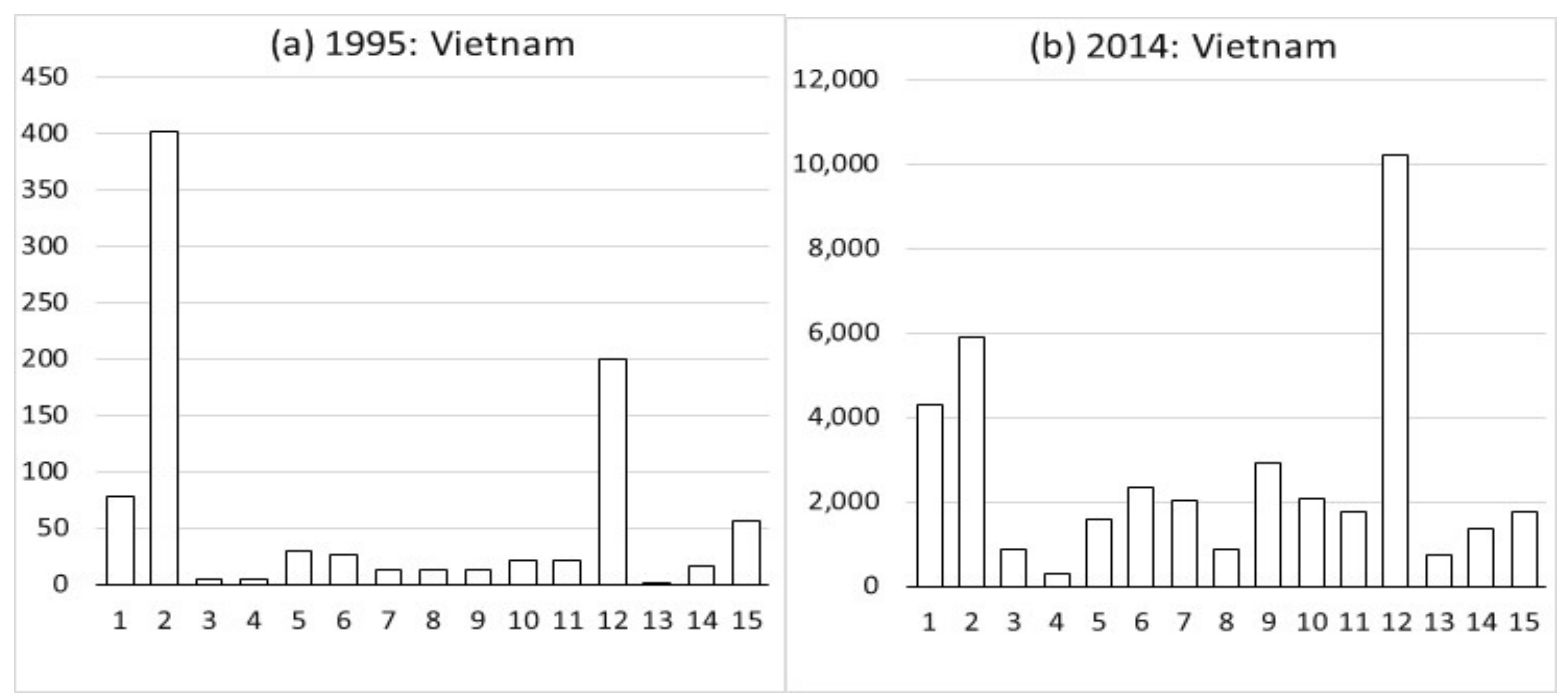

Figure 7. International production sharing across 15 manufacturing industries in Vietnam

It is evident that in 1995 the "computer, electronic and optical equipment" sector exhibited the highest FVP value in China and the second highest in Vietnam. In 2014 this sector records the highest production sharing in both countries with an almost explosive expansion, especially in China. The "textiles, textile products, leather and footwear" industry represents the next most important international production sharing industry in China as well as in Vietnam. In summary, the evidence indicates that production sharing in China and Vietnam has grown considerably. This implies that foreign firms have offshored various production segments to those economies due to, for instance, comparative cost advantages and related considerations.

\section{Export Development and its Connection to Production Sharing}

Next, we examine the developments in domestic value-added exports (DVEXP). This measure shows the value of a country's exports without the foreign value-added included (imported intermediate inputs). We consider only the domestic value-added amount embedded in a country's exports, as we interested in examining the connection and relationship between international production sharing and the domestic content of a country's exports (the value-added that is produced domestically).

Production sharing involves the inclusion of foreign value-added intermediate inputs (or production segments) into a country's domestic production, and thus also into a country's gross exports (which consist of foreign value-added and domestic value-added). If gross exports were to be considered, then the foreign value-added would also be present in the exports. For an analysis of the connection and correlation between production sharing and export development, this approach would be flawed and misleading as the FVP value is included in both measures. 


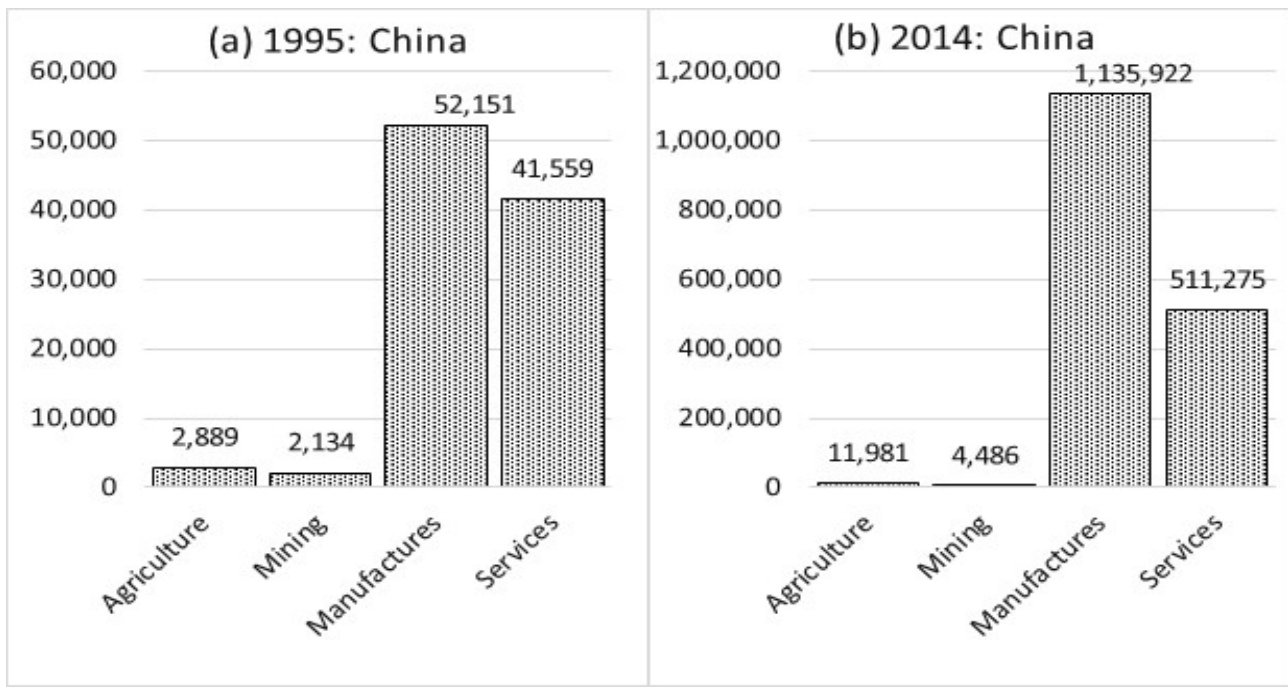

Figure 8. Exports across broad economic sectors in China

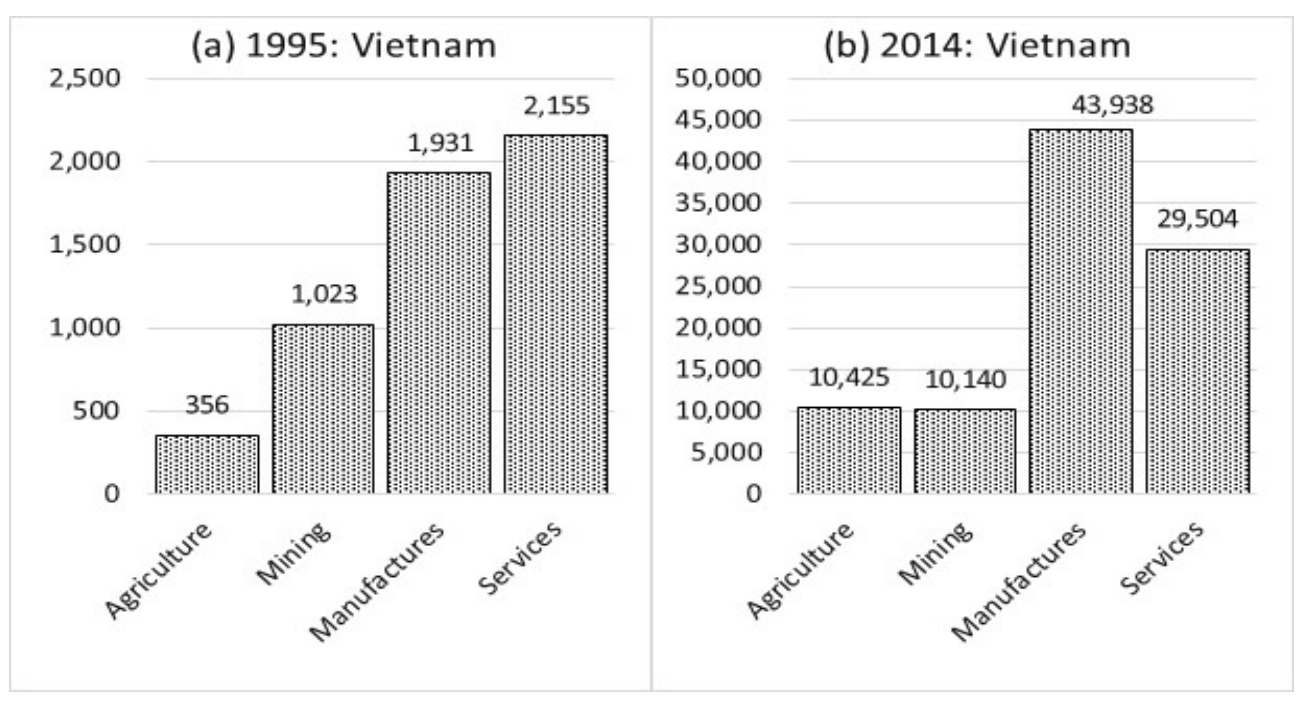

Figure 9. Exports across broad economic sectors in Vietnam 


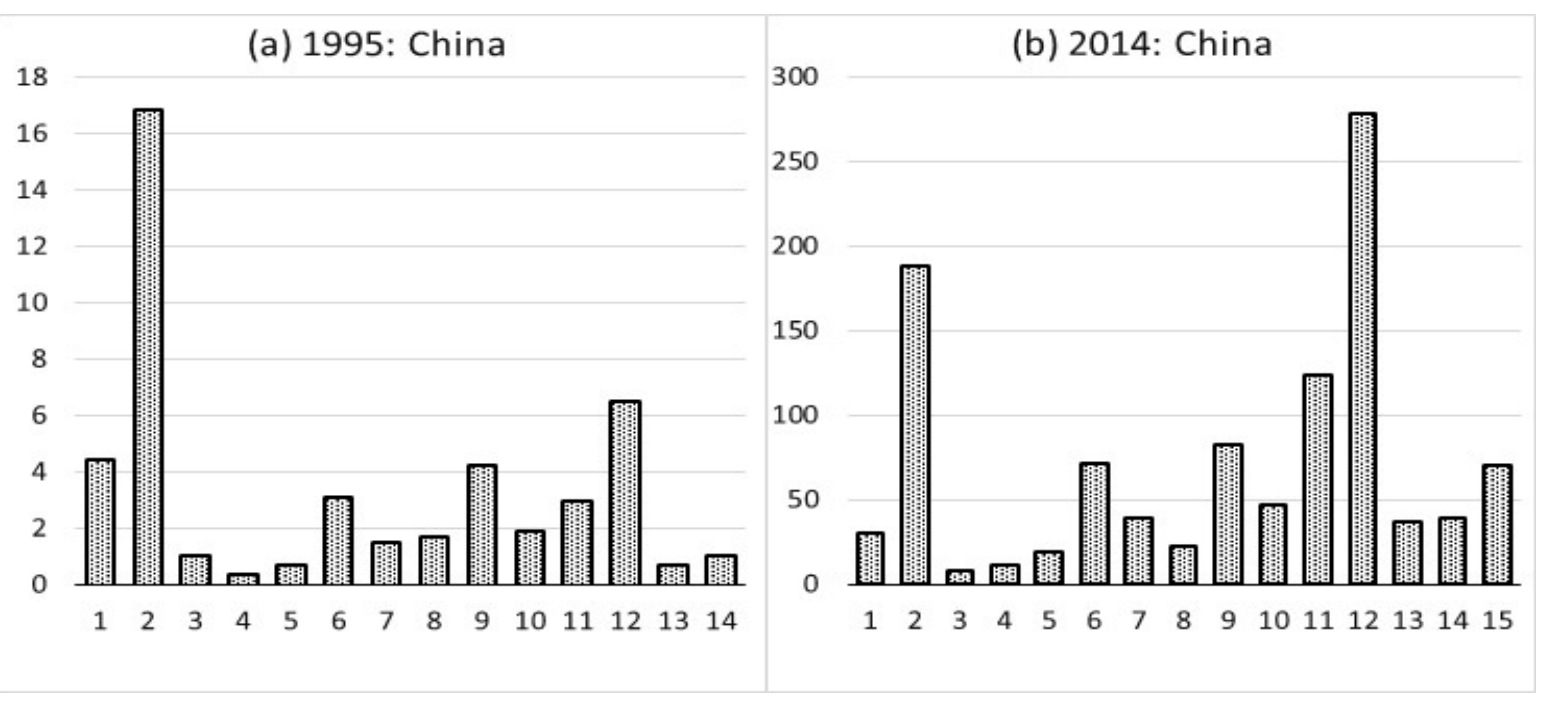

Figure 10. Exports across 15 manufacturing industries in China

Figures 8 and 9 present the trends in DVEXP across four broad economic sectors between 1995 and 2014 in China and Vietnam, respectively. In China in 1995 the manufacturing sector exhibited the highest (domestic value-added) exports, closely followed by the service sector. During the twenty-year period the ranking of sectors has not changed. However, the manufacturing sector experienced a huge export expansion, making it by far the most outward oriented sector. Agriculture and mining show a very low export value. The patterns in Vietnam do not match exactly China's export patterns. More specifically, in 1995 domestic value-added exports of the service sector are higher compared to those of manufacturing. In 2014 the manufacturing sector exhibits the highest value of DVEXP, as manufacturing has experienced a sizable export expansion during the 1995-2014 period.

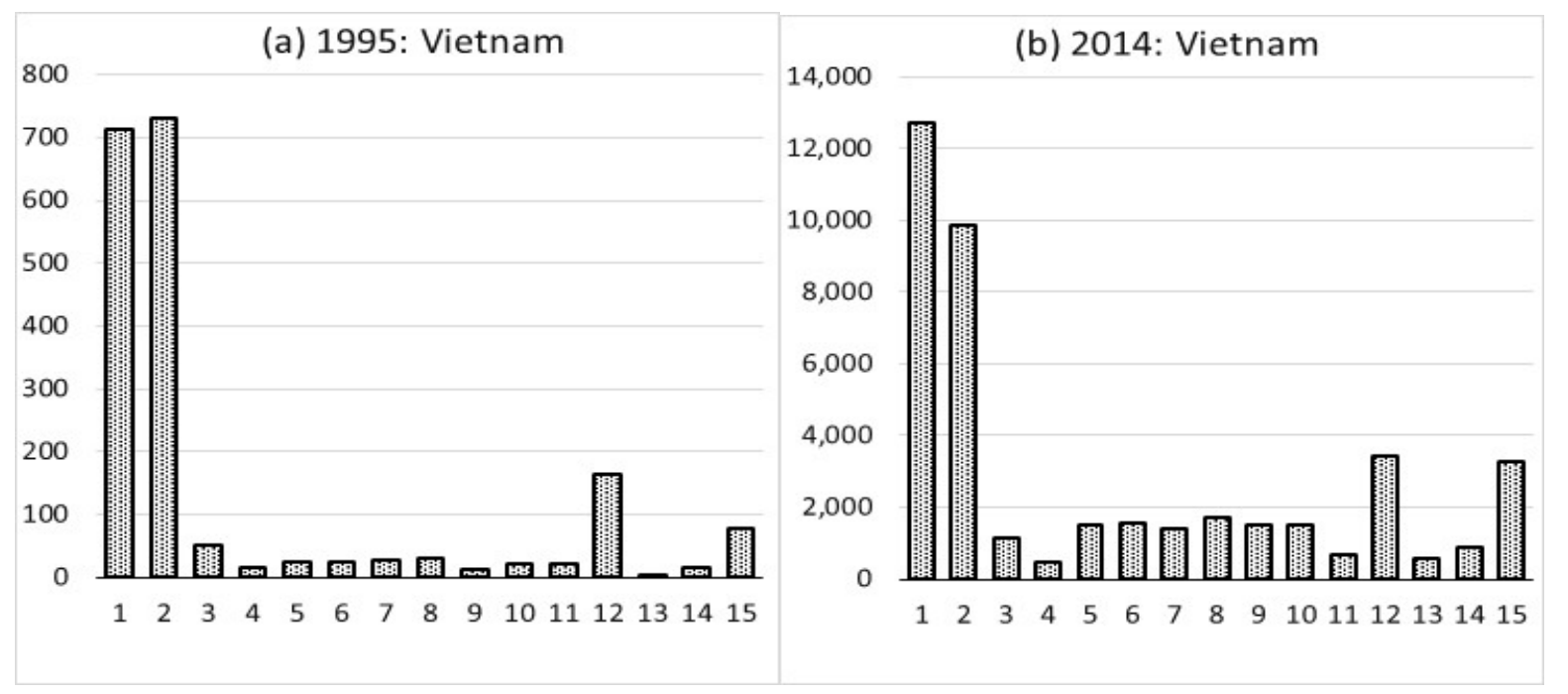

Figure 11. Exports across 15 manufacturing industries in Vietnam 


\section{Macrothink}

Unlike the situation in China, it is evident that Vietnam's manufacturing exports do not completely dominate Vietnam's total domestic value-added exports. The export share distribution across sectors is relatively more balanced. As manufacturing is clearly the most important sector with respect to exports, we examine in more detail the developments in domestic value-added exports across 15 manufacturing industries (as classified according to Table 1). From Figure 10 it is apparent that two industries, namely "computer, electronic and optical equipment" and "textiles, textile products, leather and footwear", exhibit the highest exports in China.

Those industries were also the ones with the highest extent of international production sharing, as evidenced by the FVP measure. In Vietnam, these two sectors are amongst the most export-oriented. However, the "food products, beverages and tobacco" industry shows the highest export value (Figure 11). By looking at the cross-sectoral patterns of production sharing as well as export performance, it seems that more involvement in production sharing (FVP) is associated with more exports (DVEXP).

In order to examine this in more detail and rigorously, we conduct two correlation analyses for each country. More specifically, we calculate the Pearson correlation coefficient between FVP and DVEXP and its statistical significance level for our two panel-data samples. This correlation coefficient, which takes values between -1 and 1 shows the sign (positive or negative) and the strength of a linear association / relationship. A coefficient value close to zero indicates no association, whilst a large value indicates a strong correlation. The first sample consists of the four broad economic sectors over 1995-2014, and the second consists of 15 manufacturing industries during the 1995-2014 period. Hence, the correlation analysis for the first sample provides evidence across the broad economic sectors, whilst the second correlation analysis focuses on the manufacturing industries.

Table 2 reports the results of the two correlation analyses for China and Vietnam. First, for the broad economic sectors it is apparent that in both countries there exists a strong positive relationship between FVP and DVEXP. The Pearson correlation coefficient exhibits a very high (positive) value. Moreover, the estimated correlation is highly statistically significant, as evidenced by the very small p-value (at three decimal points it appears zero). A low p-value indicates strong evidence in favor of the existence of a correlation / linear relationship between the two variables. With respect to the analysis for the manufacturing sectors, the results show that in China there is again a very strong positive and statistically significant association between the two economic phenomena. In Vietnam this positive correlation is relatively weaker, as indicated by the smaller Pearson correlation coefficient value. However, there is still evidence in favor of a significant positive relationship. 
Table 2. Correlation Analysis between FVP and DVEXP

\begin{tabular}{lcccccc}
\hline & \multicolumn{2}{c}{ Broad Economic Sectors } & & \multicolumn{2}{c}{ Manufacturing Industries } \\
\cline { 2 - 3 } \cline { 5 - 6 } & China & Vietnam & & China & Vietnam \\
\hline Correlation & 0.8975 & 0.8885 & & 0.8794 & 0.6746 \\
p-value & 0.000 & 0.000 & & 0.000 & 0.000 \\
Observations & 80 & 80 & & 300 & 300 \\
\hline
\end{tabular}

Note. p-value denotes probability value and shows the statistical significance level.

Thus, the picture that emerges is that a higher extent of international production sharing within manufacturing correlates strongly with higher exports across manufacturing industries. Though we do not examine causality, based on conceptual and theoretical grounds this positive association can be attributed, at least partly, to production sharing. Section 2 provides a discussion and possible reasons for such a causal link to exist. Under this view, China's and Vietnam's involvement in international vertical production sharing networks has contributed to export development.

\section{Concluding Remarks}

The paper has provided some empirical evidence on the relationship between a country's participation in international production sharing networks and a country's export development in terms of the domestic value-added content of exports. More specifically, our empirical analysis, which employs relevant data on global production networks from the OECD TiVA database, is conducted for China and Vietnam over the 1995-2014 period for four broad economic sectors as well as for fifteen manufacturing industries. The examination focuses on those two countries, because they are extensively involved in production sharing networks.

Our empirical results show that for both countries, China and Vietnam, international production sharing highly correlates with increased export performance. This suggests that China's and Vietnam's impressive export expansion during the last twenty years, can be attributed, at least in part, to increasing integration into international value-chain networks. The importance of this finding lies in the fact that the expansion of exports relates to the domestic value-added content of the exports (without including the foreign value-added). Hence, increased international production sharing does not only contribute to an economy's overall gross exports, but also raises the locally produced content of a country's exports.

Our findings hint at an important policy implication for China, Vietnam, and other emerging economies. A more extensive involvement in international production sharing networks is expected to affect positively a developing country's long-run export development. Under this perspective, thus, governments should pursue strategic policies that, on the one hand, promote openness to international trade and investment, and on the other hand, effectively connect their national economies with global value-chain networks. 


\section{References}

Amador, J., \& Cabral, S. (2009). Vertical Specialization across the World: A Relative Measure. North American Journal of Economics and Finance, 20, 267-280. https://doi.org/10.1016/j.najef.2009.05.003

Amighini, A. (2005). China in the international fragmentation of production: Evidence from the ICT industry. European Journal of Comparative Economics, 2, 203-219.

Ando, M., \& Kimura, F., (2009). Fragmentation in East Asia: Further Evidence. ERIA discussion paper, No. 2009-20, Economic Research Institute for ASEAN and East Asia, Jakarta.

Arndt, S. W. (2001). Offshore and Production Sharing in Preference Areas. In: Arndt, S.W. and Kierzkowski, H. (Eds.), Fragmentation, New Production Patterns in The World Economy, Oxford University Press.

Arndt, S. W., \& Kierzkowski, H. (Eds.) (2001). Fragmentation: New Production Patterns in the World Economy, Oxford University Press.

Athukorala, P. (2017). China's evolving role in global production networks: Implications for Trump's trade war. Working Paper No. 2017/08, Crawford School of Public Policy, Australian National University.

Athukorala, P. (2014). Global Production Sharing and Trade Patterns in East Asia. In Inderjit N. Kaur and Nirvikar Singh (Eds.), The Oxford Handbook of the Economics of the Pacific Rim (pp. 333-361). Oxford University Press. https://doi.org/10.1093/oxfordhb/9780199751990.013.014

Baldone, S., Sdogati, F., \& Tajoli, L. (2007). On some effects of international fragmentation of production on comparative advantages, trade flows and the income of countries. The World Economy, 30, 1726-1769. https://doi.org/10.1111/j.1467-9701.2007.01054.x

Baldwin, R., \& Robert-Nicoud, F. (2014). Trade-in-Goods and Trade-in-Tasks: An Integrating Framework. Journal of International Economics, 92(1), 51-62. https://doi.org/10.1016/j.jinteco.2013.10.002

Bonham, C., Gangnes, B., \& Van Assche, A. (2007). Fragmentation and East Asia's information technology trade. Applied Economics, 39(2), 215-228. https://doi.org/10.1080/00036840500427635

Bridgman, B. (2012). The Rise of Vertical Specialization Trade. Journal of International Economics, 86(1), 133-140. https://doi.org/10.1016/j.jinteco.2011.08.016

Cieslik, A. (2009). Foreign Direct Investment and the Volume of trade: The case of Poland. Economic Change and Restructuring, 42(4), 273-291. https://doi.org/10.1007/s10644-009-9072-x

Chiappini, R. (2012). Offshoring and Export Performance in the European Automotive $\begin{array}{llll}\text { Industry. Competition } \quad \& \quad \text { Change, } & \text { 323-342. }\end{array}$ https://doi.org/10.1179/1024529412z.00000000020

Deardorff, A. V. (2001). Fragmentation in Simple Trade Models. North American Journal of Economics and Finance, 12(2), 121-137. https://doi.org/10.1016/s1062-9408(01)00043-2 
Grossman, G., \& Helpman, E. (2002). Integration versus Outsourcing in Industry Equilibrium. Quarterly Journal of Economics, 117(1), 85-120. https://oi.org/10.1162/003355302753399454

Gupta, P. (2017). Global production networks. In: Kenneth A. Reinert (Ed.). Handbook of Globalisation and Development (pp. 153-168). Edward Elgar Publishing. https://doi.org/10.4337/9781783478651.00016

Haddad, M. (2007). Trade integration in East Asia: The role of China and production networks. World Bank Policy Research Working Paper, No. 4160, The World Bank. https://doi.org/10.1596/1813-9450-4160

Hanson, G. (2017). What Do We Really Know about Offshoring? Industries and Countries in Global Production Sharing. Centro Studi Luca d'Agliano Development Studies Working Paper No. 416. https://doi.org/10.2139/ssrn.2980947

Hiratsuka, D. (2008). Production fragmentation and networks in East Asia characterized by vertical specialization. in Hiratsuka, D. and Uchida, Y. (Eds.), Vertical specialization and economic integration in East Asia (pp. 91-116). Institute of Developing Economies, Japan.

Hummels, D., Ishii, J., \& Yi, K.M. (2001). The nature and growth of vertical specialization in world trade. Journal of International Economics, 54(1), 75-96. https://doi.org/10.1016/s0022-1996(00)00093-3

Ing, L. Y., \& Kimura, F. (Eds.) (2017). Production Networks in Southeast Asia, Routledge, London and New York. https://doi.org/10.4324/9781315406787

Jones, R. W., \& Kierzkowski, H. (1990). The role of services in production and international trade: A theoretical framework. In: R.W. Jones and A. Krueger, (Eds.). The Political Economy of International Trade, Basil Blackwell, New York.

Kimura, F., \& Ando, M. (2005). Two-dimensional fragmentation in East Asia: Conceptual framework and empirics. International Review of Economics and Finance, 14(3), 317-348. https://doi.org/10.1016/j.iref.2004.12.005

Kimura, F., \& Obashi, A. (2008). East Asian Production Networks and the Rise of China: Regional Diversity in Export Performance. KEIO/KYOTO Discussion Paper, 2008-004, KEIO UNIVERSITY.

Lall, S., Albaladejo, M., \& Zhang, J. (2004). Mapping fragmentation: Electronics and automobiles in East Asia and Latin America. Oxford Development Studies, 32(3), 407-432. https://doi.org/10.1080/1360081042000260601

Li, X. (2009). Free trade agreements and vertical-specialisation in East Asia. Asia Europe Journal, 7(1), 145-160. https://doi.org/10.1007/s10308-008-0215-X

Markusen, J., \& Venables, A. (2007). Interacting Factor Endowments and Trade Costs: A Multi-Country, Multi-Good Approach to Trade Theory. Journal of International Economics, 73(2), 333-354. https://doi.org/10.1016/j.jinteco.2007.03.005

Miroudot, S., \& Ragoussis, A. (2009). Vertical Trade, Trade Costs and FDI. OECD Trade Policy Working Papers, No. 89, Organization of Economic Cooperation and Development, Paris. https://doi.org/10.1787/222111384154

Sanyal, K. K., \& Jones, R. W. (1982). The theory of trade in middle products. American 


\section{Macrothink}

Journal of Asian Development

ISSN 2377-9594 2017, Vol. 3, No. 2

Economic Review, 72(1), 16-31.

Srholec, M. (2007). High-Tech Exports from Developing Countries: A Symptom of Technology Spurts or Statistical Illusion?. Review of World Economics, 143(2), 227-255. https://doi.org/10.1007/s10290-007-0106-z

\section{Copyright Disclaimer}

Copyright for this article is retained by the author(s), with first publication rights granted to the journal.

This is an open-access article distributed under the terms and conditions of the Creative Commons Attribution license (http://creativecommons.org/licenses/by/4.0/). 